WIELKIE TEMATY KULTURY W LITERATURACH SŁOWIAŃSKICH

Slavica Wratislaviensia CLXVIII • Wrocław 2019•AUWr No 3875

DOI: $10.19195 / 0137-1150.168 .48$

Data przesłania artykułu: 15.09.2017

Data akceptacji artykułu: 4.12.2017

ANDRIJANA KOS-LAJTMAN

Učiteljski fakultet Sveučilišta u Zagrebu, Chorwacja

\title{
Smrt kao dvostruki eksces u poeziji Darka Cvijetića
}

\section{Tematika smrti u pjesništvu Darka Cvijetića}

Iako su motivi stradanja i smrti obilježili stvarnost kao i njezinu književnu transpoziciju na cjelokupnom post-jugoslavenskom prostoru na prijelazu stoljeća, učestalost takvih tema ni u jednoj regiji nije tako intenzivna kao na području Bosne i Hercegovine ${ }^{1}$. Razlozi za to vrlo su očiti - ratni sukobi upravo su tu bili najintenzivniji, s najvećim brojem ljudskih žrtava. Ipak, čak i u kontekstu bosanskohercegovačke književnosti na prijelazu stoljeća nemoguće je pronaći opus koji bi u toliko mjeri korespondirao s tematikom smrti - prije svega u kontekstu ratne i postratne stvarnosti, ali i drugih specifičnih varijanti smrti kao što su one uzrokovane bolešću ili nesretnim slučajem. Smrt, ali i stanja koja joj prethode, koja je prate ili iz nje proizlaze, čine temeljni semantički okvir većine Cvijetićevih tekstova ostvaren kroz široku lepezu motiva od kojih su mnogi dokumentarni. Riječ je, naime, o opusu koji trenutno obuhvaća deset zbirki: Noćni Gorbačov (1990), Himenica (1996), Manifest mlade Bosne (2000), Passpord for Sforland (2004), Masovne razglednice iz Bosne (2012), Konopci s otiskom vrata (2013), Mali ekshumatorski eseji (2015), Emotioni u Viberu (2016), Paraolimpijske himne (2017) i Ježene kožice (2017). Jedna zbirka je prozna (Manifest mlade Bosne), tri su hibridne (Emotioni u Viberu, Paraolimpijske himne, Ježene kožice), dok su ostale zbirke pjesničke. Gledano u cjelini, brojem tekstova, ali i njihovom prirodom, Cvijetić je prije svega pjesnik te će se i ovaj rad temeljiti na analizi njegovih pjesničkih tekstova.

${ }^{1}$ Usporediva s bosanskohercegovačkom književnošću prema značenju i ulozi ratne problematike u tom je smislu jedino hrvatska književnost 90-ih godina 20. stoljeća, gdje je moguće govoriti o nekoliko specifičnih modela ratnoga diskursa/pisma (usp. E. Kovač, Amazonke, vile i satirice, Čakovec 2011). 
Pogledamo li godine izdanja, uočit ćemo da je samo prva zbirka, Noćni Gorbačov, objavljena prije ratnih zbivanja u bivšoj Jugoslaviji, točnije, neposredno pred njihov osvit. Ipak, čak i toj zbirci u kojoj nema eksplicitnih referencija na ratni kontekst, motivi smrti, uz pripadajuću slutnju tame, zla, tmurnih pa i apokaliptičkih slika, vrlo su prisutni. Za ilustraciju poslužit će već i osvrt na neke naslove pjesama iz te, prve Cvijetićeve zbirke: Ubijanje drvenkonjića, Raskoljnikovljeva, Poginulog, Noćni Gorbačov, O Galipolju, Niska, niska, kalašnjikov itd. Dominantan ton jest otpor/bunt (generiran radikalnim pjesničkim postupcima šoka i začudnosti ${ }^{2}$ ) povezan s neekspliciranim osjećanjem tamih strana ljudskoga postojanja.

Sve ostale Cvijetićeve zbirke svoju primarnu, iako ne i jedinu referenciju pronalaze u ratnoj i postratnoj stvarnosti Bosne presudno obilježenoj stradanjima, masovnim grobnicama, osobnim, ali i kolektivnim patnjama, postratnim iskapanjima, različitim vrstama osobnih, kao i društvenih invaliditeta. Mladenačke zbirke Noćni Grbačov i Himenica značajnije su obilježene poetikom šoka i tonom bunta, alogičnim konstrukcijama i zaumnošću, dok se fomalno oslanjaju na postupke prevrednovanja tradicionalnih pjesničkih oblika (najčešće soneta); u kasnijim zbirkama atmosfera pobune se smiruje, prerastajući, postepeno, u dokument o jednom vremenu i njegovim tragičnim, nerijetko apsurdnim praksama. To je posebno vidljivo u zbirkama nastalima u drugom desetljeću novoga stoljeća (od Masovnih razglednica iz Bosne naovamo) koje su u značajnoj mjeri obilježene dokumentarnošću, stišavanjem retoričke geste, 'poetikom svjedočenja' te hibridnim pjesničko-proznim oblicima kao što su oni u zbirci Emotikoni $u$ Viberu. Tekst, iako još uvijek obilježen nekim prepoznatljivim autorskim poetičkim karakteristikama - u prvom redu onima koje bismo mogli podvesti pod nazivnik neoavangarde, a koje se prije svega očituju kroz začudne neologizme i beskompromisnu društvenu angažiranost - prvenstveno ima funkciju spomenika, svjedoka o nečovječnoj strani vremena i društva kojega smo dio, a koje nije samo odrednica regije koju tematiziraju, nego često ukazuje na apsurd bivanja uopće. Iako, dakle, formalnim strategijama ponešto različite, sve Cvijetićeve zbirke dosljedne su u svom tematskom i svjetonazorskom horizontu i teško im je naći pandan u nekom drugom opusu slavenskog konteksta. Tema smrti semantička je jezgra cijeloga opusa koji specifičnim pjesničkim jezikom generira svojevrsnu poetiku smrti, konstruiranu na poetskoj galerizaciji mrtvih i ranjenih u skladu s teorijski već prepoznatom postmodernističkom sklonosti skladištenju i muzealizaciji ${ }^{3}$, a za koju, nažalost, stvarnost autorova životnog konteksta nudi i više nego bogato motivsko uporište. Racionalna neprihvatljivost takvog poretka svijeta i čovjekova mjesta u njemu ono je što u svjetonazorskom sloju također povezuje ove zbirke u kompaktnu cjelinu.

\footnotetext{
${ }^{2}$ Usp. A. Flaker, Poetika osporavanja, Zagreb 1982.

${ }^{3}$ Usp. M. Šuvaković, Postmoderna (73 pojma), Beograd 1995, s. 113.
} 
Promatramo li navedeni opus kontekstualno, u književnopovijesnom okviru, još se jedna njegova dimenzija nameće kao osebujna i znakovita. 90-te su godine na prostorima bivše jugoslavenske države (osobito Bosne i Hercegovine i Hrvatske kao najpogođenijih ratom) oblikovale „vrlo slojevit sustav budući da su motivirajući momenti vrlo raznoliki i brojniji nego inače ${ }^{\star 4}$. Prevladavajući pristupi, međutim, bili su oni - kako u pjesništvu tako i u prozi - koji su označili zaokret od jezične zaigranosti, ,želeći djelovati kao «zrcalo stvarnosti», imati spoznajnu funkciju”. Mijenja se i žanrovska slika književnosti koja je 80 -ih bila obilježena postmodernističkim ludizmom i hibridizacijom iskaza i formi, da bi se 90 -ih, u kontekstu promijenjene stvarnosti, dogodilo ono o čemu piše i Hayden White govoreći o situacijama tragičnih događaja kakvi su masovni pokolji ili genocid - da pisanje o takvim događajima u pravilu zahtijeva uzvišene žanrove kakve su tradicionalno predstavljali ep i tragedija ${ }^{6}$. U kontekstu suvremenog postmodernog doba takvi su žanrovi, dakako, anakroni, pa njihove funkcije u specifičnim kriznim vremenima preuzimaju drugi oblici 'uzvišenog govora', iskaza visokoga registra, što je osobito čest slučaj s tekstovima pisanima u samom ratu ${ }^{7}$ Predrag Finci ukazuje na činjenicu da u ratu nastaje niz „kič-produkata“ lošeg stila, prozirne metaforike, uglavnom 'patriotskog prototipa' koji je u službi ratne ideologije ${ }^{8}$. U fazama nakon rata pristupi se usložnjavaju prerastajući okvir stvaralaštva „trenutka zbog trenutka“99. Iako ovakva razdioba poetičkih praksi prema trenutku nastanka diskursa o ratu nije presudna za ovaj rad, za Cvijetićeve je pjesničke iskaze karakteristično da ih nikad ne obilježavaju odrednice patriotskog govora i predvidljivog stila te da je riječ o opusu koji inzistiranjem na arističkoj dimenziji označitelja, eksperimentalnosti i začudnosti, predstavlja izuzetak (ili jedan od rijetkih) u produživanju onih poetičkih tijekova, bitno utemeljenih u jeziku kao referentu, kakve su na ovim prostorima donijele 70 -te i 80 -te godine 20 . stoljeća, da bi ih 90-te naprasno prekinule.

\section{Ekscesnost smrti kao ekscesnost jezika}

\section{Smrt kao referent}

Najvažnije obilježje smrti kao referenta u Cvijetićevu pjesništvu, osim učestalosti, jest priroda smrti. Gotovo uvijek to je neočekivana smrt koja u intimnom i/ili socijalnom okolištu u kojem se događa ima status ekscesa, često na granici bizarnosti i/ili apsurda. Nekoliko je tematskih sfera koe se s obzirom na specifičnosti takvog referenta mogu izlučiti u ovome opusu.

${ }^{4}$ E. Kovač, Amazonke, vile i satirice, Čakovec 2011, s. 27.

5 Ibidem, s. 27.

${ }^{6}$ H. White, Figural Realism: Studies in the Mimesis Effect, Baltimore 1999, s. 31.

7 A. Demiragić, Prikaz rata u tekstovima bosanskohercegovačkih spisateljica: žensko ratno pismo 1992.-1995., doktorska disertacija, Filozofski fakultet u Sarajevu 2015.

${ }^{8}$ P. Finci, Umjetnost uništenog: estetika, rat i Holokaust, Zagreb 2005, s. 68-69.

${ }^{9}$ Ibidem, s. 72. 


\section{Ratna stvarnost}

Najčešći kronotopski kontekst koji se rasvjetljava tematizacijom smrti u pjesništvu ovoga autora jest rat i ratna stvarnost. Nebrojeno mnogo je primjera, od prve autorove poslijeratne zbirke Himenica (1996), pa do posljednje zbirke Ježene kožice (2017). Himenica je objavljena neposredno nakon rata, a pisana u vrijeme rata te je u njoj atmosfera 'vruća', obilježena poetikom šoka koja u prvom redu proizlazi iz ekspresivnih i/ili nadrealnih slika, aleatoričnih konstrukcija i mjestimice zaumnog jezika. No čak i u toj zbirci šokantnost ratnih prizora u kontrapunktu je s emotivnom ogoljenošću/mirnoćom koja je konstantna te se može tumačiti kao ingerentna autorska strategija koja osobito dolazi do izražaja u kasnijim zbirkama gdje je udio dokumentarnosti sve veći, a tekstualni oblici sve duži i hibridniji. Donosimo nekoliko primjera motiva smrti u okrilju ratne stvarnosti iz različitih zbirki: „Anđelo rovski drug mojeg brata. / Bombom raznio usta gol pored vode.“ (Zalutkivanje angela, zbirka Himenica); „Okopala je oca sa sedam godina. / Petnaestog su pale četiri na grad. / Zimopis Jeruzalema po Luki.“ (Ekavski prepjev Osipa, zbirka Himenica); Zarobljenog su polili vodom. / Golog. / Možda sedamnaest godina. / (kao haiku slogova) / Pod sleđenim dudom. / [...] / Drhtao plakao prestao / [...] / Curicu raznijela granata.“ (Što može pjesma, zbirka Konopci s otiskom vrata); „Izveli 200 ljudi iz autobusa / i pobili nad provalijom“ (Poslanica Korićanima, zbirka Konopci s otiskom vrata); „Umorno sam gledao kako uvečer 31. V. 1992. / Gori gradska džamija / Od vojske zapaljena / S prozora solitera vidio sam munaru / Kako pada u oganj“ (Ukratko o ratu, zbirka Mali ekshumatorski eseji).

S obzirom da tzv. sociologija smrti ${ }^{10}$ poznaje odrednice pojedinih društvenih konteksta smrti i načine njihova djelovanja na civilizacijske prakse umiranja, poznato je da je rat vrlo specifičan kontekst koji uvelike mijenja uobičajenu percepciju smrti iz temeljnog razloga jer ratno stanje ,označuje univerzalan (i suvremen) primjer iščezavanja prisutnosti smrti zato što je potvrđivanje društva nadvladalo potvrđivanje individualnosti“"11. Temeljno obilježje društvenog stanja u ratu jest posjedovanje jedinke od strane države, ističe Edgar Morin u svojoj opsežnoj bioantropološkoj studiji Čovjek $i$ smrt - društvo u ratu postaje biološka vrsta, posebnost jedinke je potisnuta $u$ drugi plan u trenutku kada se radi o borbi za život i smrt: „Dakle, utopljen unutar svoje grupe koja je u opasnosti ili u pokretu, mučenik, borac, stanovnik opsjednutog grada ili križar više se ne boji

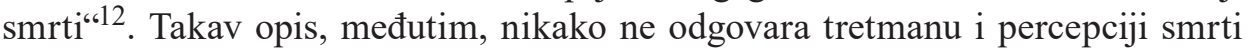
u Cvijetićevu pjesništvu, štoviše, predstavlja njegov kontrapunkt. Slike koje nalazimo u pjesmama ovog autora, bez obzira jesu li dokumentarno utemeljene ili rezultat transpozicije stvaralačke imaginacije, ukazuju na posve suprotne kategorije: na strah koji prožima ljudsko biće u svim njegovim suštinskim dimenzijama

\footnotetext{
${ }^{10}$ Usp. M. C. Kearl, Endings: A Sociology of Death and Dying, New York-Oxford 1989.

${ }^{11}$ E. Morin, Čovjek i smrt, Zagreb 2005.

12 Ibidem, s. 59.
} 
(svodeći ga nerijetko na situacije fizičkog i psihičkog poniženja), ali i na duboku usamljenost koja, upravo suprotno nego se događa u situacijama kolektivne identifikacije, proizlazi iz njegove pojedinačnosti. Takva je pojedinačnost u kontekstu najtežih ratnih stradanja nužno tragična, ali često i duboko apsurdna. Iz konotativnih nanosa takvih pjesničkih slika širi se polje mogućih simboličkih tumačenje ljudskoga zla, odnosno fizičke i psihičke poniženosti kao njegovih posljedica.

\section{Postratna stvarnost}

Tematski kompleks postratne stvarnosti u Cvijetićevu je opusu prisutan gotovo u jednakoj mjeri kao i kompleks samoga rata. Udio slika koje se odnose na postratnu stvarnost sve je veći s udaljavanjem od ratnoga perioda, odnosno od Masovnih razglednica iz Bosne prema posljednjim Cvijetićevim zbirkama. Istovremeno u njima opada zastupljenost motiva iz neposrednog ratnog života (slike s fronta), što pak je u skladu s onim o čemu piše Miriam Cooke govoreći o ratnoj i postratnoj tematizaciji rata, a gdje naglasak stavlja upravo na postratni period koji izravno utječe na percepciju rata, mijenjajući joj motive i ton. Doduše, Cooke govori o narativnim formama, no nema razloga da se iz toga principa izuzme pjesništvo. Cooke tematizira tzv. period poratne paralize ${ }^{13}$ koji sagledava kao 'smrznuto vrijeme' u kojem postaje jasno da su ratni gubici bili uzaludni, da se ciljevi nisu ostvarili ili su ih unakazile poslijeratne politike, što dovodi do apatije i gubitka vjere da su moguća ikakva konstruktivna rješenja. U takvim periodima razočarenja rat biva podloga za sagledavanje aktualnog trenutka i njegovih zastranjenja $^{14}$. Upravo takav odnos prema zbilji kao stanju paraliziranih silnica između jedinke i društva koje se ratnim razaranjima i pokoljima nepovratno promijenilo - mijenjajući time povratno i pojedinca (fizički, mentalno, emocionalno, ideološki, itd.) - paradigma je Cvijetićeva pristupa postratnoj stvarnosti. Simboličko mjesto takve stvarnosti jest masovna grobnica koja postaje ne samo najčešći motiv Cvijetićeve poezije posljednjeg desetljeća nego i simbolička poetska figura života uopće, obilježenog rasapom, potragom i neizvjesnošću. Iz toga se generira fenomenologija trajne ranjivosti kao nemogućnost pronalaska konačnog smirenja i/ili točke smislenog uporišta kao ključan spoznajno-emotivni sloj ove poezije. Poetika ranjivosti ${ }^{15}$ stoga je sintagma koja dobro prezentira suštinu Cvijetićeve postratne poezije, ukazujući kako na njezin semantički tako i na sintagmatski ustroj koji je također obilježen rasapom, distancom, neologizmima pa i mjestimičnim odmakom od normativnog sintaktičkog ustroja. Rane (kako fizičke, tako i psihološke, ali i kolektivne, simboličke) funkcioniraju kao prošivni bod ${ }^{16}$ ove

${ }^{13}$ M. Cooke, Deconstructing war discourse: Women's Participation in the Algerian Revolution, [u:] Women and International Development, prir. A. Ferguson, East Lansing 1989.

14 Ibidem.

15 Usp. A. Kos-Lajtman, Poetika iskopavanja, kartografija ranjivosti, [u:] D. Cvijetić, Paraolimpijske himne, Ljubljana 2017.

${ }^{16}$ Mjesto na kojemu dolazi do zaustavljanja u označiteljskom lancu Lacan naziva ,prošivni bod (point de capiton) “ kojim se jezični sustav kao beskonačni performativ pretvara u konstativ kon- 
poezije, čvorišna točka koja zaustavlja značenjsko klizenje pojedinih tekstova, ali i 'prošiva' opus u cjelini.

Nekoliko primjera tematiziranja postratne stvarnosti kao značenjske pozadine za motiv smrti: „Jednoj su majci jučer saopćili da su u masovnoj / grobnici u Tomašici našli njezinih šest sinova i / muža“ (Drugi obraz, zbirka Mali ekshumatorski eseji); „Kada su otvorili masovnu na / Jakarinoj kosi dvijeidvanaeste / Sa 373 tijela / Vidjeli su I.G. (1968.) kako čuči / U materinoj košulji“ (Bicikl od kose, zbirka Konopci s otiskom vrata); „A pored Prijedora, jedan sin, u trošnoj kućici na / periferiji, prošle godine, / tri dana je hranio mrtvu, preminulu mater. / Narod zvao policiju, lud je on još od rata, rekla je / susjeda." (Otac i sin, zbirka Mali ekshumatorski eseji); „Sin lokalnog tajkuna, prije tri mjeseca, ubio je / djevojku / koja ga je ostavila. Odmah potom i sebe.“ (Megahertz, zbirka Mali ekshumatorski eseji); „Galeta su razmijenili 1996., nekih godinu dana od pogibije. / Bili su plitko pokopani, njih petorica, oko 40 cantimetara. / Stari, pokojni Dule ga prepoznao.“ (fragment iz zbirke Emotikoni u Viberu).

Postratna stvarnost, dakle, u znaku je smrti jednako kao i ratna. Jedina je razlika u emotivno-spoznajnom naboju koji je kod potonje obilježen rezignacijom i patnjom iterativnog pronalaženja tragova smrti (rasap kostiju istoga tijela u više masovnih grobnica čest je motiv ovih tekstova), odnosno patnjom ekshumatorstva kao ponavljajućeg čina koji nikada ne prestaje. Takva semantičko-simbolička figura ujedno ima potencijal metafore povijesti (ovih prostora), gdje društvo/regija postaje palimpsest ispisan nečitkim rukopisom grobova.

\section{Smrt od bolesti ili tragičnog slučaja}

Relativno često u Cvijetićevim tekstovima, u svim fazama opusa, nalazimo motive smrti koja nije rezultat rata, niti je odrednica postratnog, ekshumatorskog perioda. To je, međutim, smrt koja se ne uklapa u okvire prirodne/očekivane smrti, već biva ekscesom odrednicama iznenadnosti, tragičnosti i/ili bizarnosti. Nerijetko, protagonisti takvih smrti jesu infantilna bića poput djece i životinja kod kojih je faktor bespomoćnosti još izraženiji, a smisleno dohvaćanje fenomenologije još teže ili sasvim nemoguće. Stoga se apsurd izdvaja kao temeljno osjećanje, ali i bitna poetska figura takvih iskaza. Puni doseg dimenzije apsurda, osobito kada su u pitanju životinje, postiže se izravnim ili aluzivnim supostavljanjem uz one konstelacije svijeta koje smatramo uobičajenim - stoga se, primjerice, situacije iz životinjskog svijeta nerijetko prilažu onima iz ljudskoga, pri čemu se izlučuje sličnost kao najčešći zajednički nazivnik, i to ona koja uglavnom izrasta iz osvješćivanja zvjerskih nagona u čovjeku/životinji. Štoviše, čovjek tu i prerasta životinje, kako zamjećuje Morin, kao ,jedina životinja koja ubija pripadnike svoje

kretne komunikacijske situacije. Lebdeći označitelji u takvim čvorišnim točkama postaju dijelom strukturirane značenjske mreže čime se proces desemantizacije fiksira i čuva od rasapa (S. Žižek, Sublimni objekt ideologije, Zagreb 2002, s. 125-126). 
vrste i kada ga na to ne prisiljava opstanak“17. Oba svijeta, životinjski i ljudski, pritom su uronjena u kontekst apsurda koji pak se na označiteljskoj razini najčešće odražava kao jezični paradoks ${ }^{18}$.

Nekoliko primjera takvih bizarnih, nedokučivih smrti: „Kada je lift u crvenom soliteru odsjekao glavu šestogodišnje / Stojanke K. bio je srpanj 1992. i rat. / Struje nije bilo već danima. / Potom je došla na četiri sata." (Volandova obljetnica, zbirka Konopci s otiskom vrata); „Kada je šesnaestogodišnja Merilin Babić ubila prvo / dijete, nitko nije primijetio." (Medejino srce, zbirka Mali eshumatorski eseji); „Došli su roditelji iz / Amerike. U zagrebačkoj / Zračnoj luci nasmiješena mama / I otac. / S ujakovom urnom / U ruksaku na leđima." (Epska, zbirka Konopci s otiskom vrata); „Klinci su između garaža / Našli cvokotavu kuju s petero / Štenadi. / Nahranili ih utoplili napojili i / Igrali se. / Zatim su koju vezali / I pred njom palicom zatukli / Štene po štene.“ (Šaptačica vučjaku, zbirka Konopci s otiskom vrata).

\section{Smrt kao označitelj}

Tematizacija smrti u ovom je pjesničkom diskursu usko povezana s označiteljskom stranom jezičnoga iskaza iz koje se derivira barem onoliko pjesničkoga potencijala koliko i iz referenecijalne razine ovoga poetskoga govora. Štoviše, temeljno svjetonazorsko, ali i teorijsko polazište koje je moguće očitavati u tretmanu jezika u Cvijetićevu pjesništvu jest ono wiittgensteinovsko, utemeljeno na uvidu o međusobnoj kompatibilnosti jezika i svijeta načinom međusobne uvjetovanosti putem logičke strukture slike ${ }^{19}$, odnosno, utemeljenosti svijeta, misli i jezika na istim principima. Svrha Wittgensteinove analize u Traktatu jest pronaći granice svijeta, mišljenja i jezika kako bi se razlikovao smisao od nonsensa, pri čemu Wittgenstein izvan okvira onoga što je moguće izreći ostavlja etičke, estetske i metafizičke principe. Svjestan granica jezika koje je sabio u okvire logike i prirodnih znanosti ovaj se filozof opredjeljuje za šutnju o svemu što leži izvan tih granica. Ipak, Wittgenstein je uvjeren da je upravo ono transcendentno najvažnije, iako je o tome nemoguće smisleno govoriti. Stoga je šutnja, kao princip za koji se zalaže, zapravo ,ispunjena šutnja kao znak priznanja neizrecivosti onoga što je iznad (izvan) svijeta“20. Smislenim govorom koji pretendira na znanstvenost ne može se izreći transcendentno, a kako tu pripada i poezija, jasno je da ni ona ne može koristiti uobičajen, unutarsvjetski jezik ${ }^{21}$, već potpuno drugi tip govora,

${ }^{17}$ E. Morin, Čovjek..., s. 90.

18 Usp. M. Solar, Retorika postmoderne, Zagreb 2005.

${ }^{19}$ Logička struktura slike, bilo u mislima ili u jeziku, izomofrna je s logičkom strukturom stanja stvari koje slika predstavlja. (L. Wittgenstein, Tractatus logico-philosophicus, prev. G. Petrović, Zagreb 2003).

${ }^{20}$ A. Periša, Poteškoće i mogućnosti govora o etičkom kod ranog Wittgensteina, „Crkva u svijetu“" 2006, br. 1, s. 82-96.

${ }^{21}$ Ibidem, s. 93. 
onaj koji je okrenut neizrecivom te balansira na rubu šutnje. Upravo to minimaliziranje govora, ali i način njegove distorzije u oneobičen ili zaumni jezik kao označitelj koji može sudjelovati u prijenosu transcendentnog, nesvakodnevnog, prisutno je ovom pjesništvu. Da je riječ o osvještenom metapoetskom pristupu, pokazuju upravo eksplicitne intertekstualne poveznice s Wittgensteinom ${ }^{22}$.

Niz je stilskopoetičkih postupaka koji su povezani s osjećanjem/stavom iskaznog subjekta da je o onom najvažnijem nemoguće govoriti 'neutralnim' jezikom racionalnosti. S obzirom da je upravo smrt čvorišna točka opusa kao fenomen maksimalnog doživljanog intenziteta kako za pojedinca tako i za njegovu okolinu, upravo je u slikama smrti najizrazitiji Cvijetićev poriv da o onom najvažnijem (ujedno i najbolnijem) valja govoriti minimalno, na rubu izgovorivosti, jezikom koji je odmaknut od 'neutralnog' označitelja. Različite su jezične geste koje pokazuju težnju smirenja ili oneobičenja iskaza, a ovdje ćemo, zbog ograničenog prostora, navesti tek najznačajnije.

Temeljno obilježje ove poezije u svim fazama jest začudni jezik. Riječ je o oneobičenim, zatamnjenim iskazima kakvi su, povijesno gledano, najkarakterističniji za avangardne prakse u 20-im i 30-im godinama prošloga stoljeća, a koje su teoretičari ruskoga formalizma prozvali efektom očuđenja (rus. ostranenie) ${ }^{23}$. Pišući o takvim avangardnim tendencijama pozitivnog vrednovanja alogičnost i nerazumljivosti, Flaker im pridaje funkciju estetskoga prevrednovanja kao geste odnosa prema tradiciji, no jezik začudnosti analizirali su i mnogi drugi. Teoretičar Vlatko Pavletić promatra ga kroz figure začuđivanja ${ }^{24}$ te će nam njegova tipologija biti od koristiti i u raščlambi Cvijetićevih postupaka kojima se smrt reflektira na označiteljskoj razini iskaza, no djelomice revidirana i prilagođena pjesničkoj praksi o kojoj govorimo.

\section{Topos izokrenutog svijeta}

Matricu poetskog izokretanja stvarnog svijeta Cvijetićeva poezija prakticira kako u smislu dijametralne tako i relativne obrnutosti, odnosno različitih razina odmaka od polaznoga smisla. U kontekstu tematiziranja smrti kao teme koja još uvijek nije sasvim detabuizirana ${ }^{25}$ većina takvih primjera doprinosi relativizaciji smrti a onda, posljedično, i života samoga. Kao paradigmu takvoga pristupa navodimo pjesmu Volandova obljetnica, o jednoj od najpotresnijih smrti koju je uopće moguće zamisiti - o situaciji gdje je, nesretnim slučajem, lift u soliteru odrezao glavu šestogodišnjoj djevojčici Stojanki K. Pjesmu donosimo u cijelosti:

Kada je lift u crvenom soliteru odsjekao glavu

šestogodišnje Stojanke K.

22 Više je takvih mjesta, primjerice, u fragmentu iz Emotikona u Viberu: „U dnevniku koji sam vodio u rovu 1995. prekrižio sam citat Wittgensteina, a dodao opis borbenog ranca s konzervom sardina iz 1966. i zapis o nadrnčanoj cijevi puščanoj“ (D. Cvijetić, Emotikoni u Viberu, Sarajevo 2016, s. 58).

${ }^{23}$ Usp. A. Flaker, Poetika osporavanja...

24 V. Pavletić, Ključ za modernu poeziju, Zagreb 1986, s. 99-130.

25 Usp. E. Morin, Čovjek..., s. 31. 
bio je srpanj 1992. i rat.

Struje nije bilo već danima.

Potom je došla na četiri sata.

I dvije su se djevojčice igrale na stubištu

drugoga kata.

Treća se vozila liftom i začuvši glasove

Ukočila ga na drugome.

Na kojem je razbijeno staklo na teškim vratima.

Stojanka K. nije otvarala vrata lifta.

Provukla je glavu kroz razbijeni otvor i dozivala

frendice.

Netko je pozvao lift.

Stojanka K. bila je prelaka za prikazivanje

težine.

Lampice su se na katovima pogasile.

Dekaptirano tijelo još se treslo u kabini

Kada je taj (netko) otvorio vrata

$\mathrm{S}$ namjerom da uđe.

Za dva će dana biti 19 godina od tada.

Još uvijek nitko nije oprao krv

Koja je i sada ogromna crvena mrlja.

Neprepoznatljiva u općoj prljavosti

međukatnog zida.

A on.

Koji ispipava presušena jaja i mrvi u njima

Bivše angele.

Sjedi na krovu lifta i drži ulje u bočici.

Nasmiješen mašući repom gleda njih dvije

Sada mlade žene.

Kako se došminkavaju u liftu.

Pred izlazak u grad. ${ }^{26}$

U navedenoj je pjesmi, nakon prvih pet strofa koje gotovo dokumentarnim jezikom iznose pojedinosti tragičnoga slučaja, ključna ona šesta, zadnja, koju možemo smatrati svojevrsnim epilogom. Upravo je to strofa koja prezentira topos izvrnutog svijeta, drugog i drugačijeg od onoga koji je bio predstavljen prethodnim strofama. U posljednjoj strofi tako nije više riječ (samo) o Stojanki K. i njezinoj tragičnoj sudbini, nego se slika i vremenski i motivski rekontekstualizira - predočava Njega, „koji ispipava presušena jaja i mrvi u njima / Bivše angele“, sjedeći na krovu lifta s uljem u bočici. Nije teško zaključiti, osobito jer to sugerira i naslov kao ključan paratekst pjesme, da je riječ o Wolandu odnosno Sotoni, liku koji je višestruko utemeljen u pisanoj tradiciji, s najpoznatijim utjelovljenjem u ulozi

${ }^{26}$ D. Cvijetić, Konopci s otiskom vrata, Prijedor 2013, s. 8-9.

Slavica Wratislaviensia 168, 2019

(C) for this edition by CNS 
ključnog protagonista romana Mihaila Bulgakova ${ }^{27}$. Ne samo da je takva slika Vraga kao onoga kome pripada epilog u slučaju mrtve djevojčice -koja, logikom svoje dobi, i nije mogla biti drugo nego „bivši angeo“ - neočekivana kao završetak pjesme, nego se ona odmiče od predočenog konkretnoga slučaja nudeći nam ujedno pjesničku interpretaciju svih sličnih slučajeva nevinih i bizarnih smrti, pa i smrti uopće, kao činjenice nad kojom zakazuje logika (moguće je još samo ono transcendentno, ono o čemu se, kako smatra Wittgenstein, ne može govoriti racionalnim jezikom). Pretpostavljiv horizont očekivanja kod većine bi čitatelja na tome mjestu zasigurno prije mogao zamisliti sliku Boga, ili barem anđela, no upravo je slika Wolanda s uljem u bočici ${ }^{28}$ simptomatična slika koja ukazuje kako na tragičnost, tako i na apsurdnost života i smrti kao fenomena spojenih posuda. Wolandu koji je u ovoj tragičnoj pjesmi zamijenio Boga/Isusa kao onoga kome pripada završna riječ, i onoga koji donosi utjehu, pridružuje se i slika dviju djevojaka koje se u liftu došminkavaju pred izlazak u grad. Iako nije eksplicirano, sintagma „njih dvije“ asocijativno priziva upravo dvije djevojčice s početka pjesme - prijateljice Stojanke K, one koje su ostale žive, a koje su bile nedokučivi kotačići u mehanizmu Stojankine smrti. Djevojke, okupirane 'došminkavanjem', s vrha lifta gleda Woland „nasmiješen mašući repom“. Je li smijeh i mahanje repom signal Wolandova zadovoljstva ili možda neke spletke/tragedije koju sprema, ostaje, dakako, otvoreno i u potpunosti prekriveno ovom burlesknom slikom. Cvijetićeva je pjesma, kao i većina njegovih pjesama koje govore o smrti, osim što je duboko tragična ujedno i oličenje životnog apsurda u svoj širini njegove (ne) shvatljivosti. Izokrenta slika svijeta puni intenzitet u ovoj pjesmi postiže upravo zahvaljujući činjenici da je riječ o događaju maksimalne emotivne snage, i to tragičnoga predznaka, kojem se, međutim, kontrapuntira slika Sotone (koji je sam po sebi antiteza nevinom djetetu), koja pak se onda još i dodatno sučeljava slici došminkavanja djevojaka pred izlazak u grad kao antipodu prethodno predočenoj smrti šestogodišnje djevojčice. Izlazak nasmijanih djevojaka kojima je glavna preokupacija nešto toliko svakodnevo, ležerno i/ili trivijalno kao što je popravljanje šminke u nekom sasvim običnom danu djeluje kao protuteža ali i kontrastni pomak 'priče' u sudbini Stojanke K. Sučeljavanjem dviju posuda klepsidre, dakako, intenzivira se dojam pjesme koji, moguće je pretpostaviti, u čitatelju odjekuje snagom unutarnje eksplozije (implozije), ostavljajući ga u temeljnoj zapitanosti nad smislom, odnosno apsurdom življenja.

${ }^{27}$ Riječ je o romanu Majstor i Margarita objavljenom prvi put 1966. godine, 26 godina nakon autorove smrti.

${ }^{28}$ Ulje je također intertekstualni motiv koji uspostavlja vezu s Bulgakovljevim romanom - u prvom poglavlju toga romana, naime, zagonetni stranac (Woland) na Patrijarškim ribnjacima u Moskvi proriče književnom uredniku Berliozu da će umrijeti tako da će mu biti odrubljena glava, zato što je komsomolka Anuška razbila bocu s uljem. To se ubrzo doista i ostvaruje tako da Berlioz pogiba pod kotačima tramvaja nakon što se poskliznuo na Anuškino ulje kod tramvajske pruge. (M. Bulgakov, Majstor i Margarita, prev. V. Flaker, Koprivnica 2012, s. 16). 


\section{Narativne tenzije}

Postupak koji Cvijetićeva poezija povremeno koristi, naročito u dužim narativnim pjesmama koje je uvjetno moguće nazvati poemama, jest postupak uspostavljanja narativne tenzije između prvog i drugog dijela pjesme, što najčešće znači između većeg dijela pjesme i njezina završetka. Najviše takvih pjesama sadrži zbirka Mali ekshumatoski eseji - takve su pjesme Rane u genizi; Vitez, hrast, miris vafla (na 72. godišnjicu pogubljenja Mire Cikote); Numerirane bilješke uz Petra Pana; Obućar kod Grimmovih. Također, takve su i pjesme Kupanje Kaina ili Maljević, Kazimir iz zbirke Masovne razglednice iz Bosne. Cvijetić je, naime, zanimljiv spoj autora koji je istodobno izrazit liričar, ali i izvrstan pripovjedač, što upravo potvrđuju pjesme poput navedenih. U svakoj od njih riječ je o konkretnoj priči ispričanoj u stihovanoj formi, najčešće dokumentarnog karaktera, gdje se prezentira cjelokupan razvoj događaja (najčešće neke tragične sudbine), pri čemu je završetak ključno mjesto priče koji se prema ostatku pjesme odnosi na način da baca novo svjetlo na ono već ispričano: demontira ga, oneobičava ili na drugi način značenjski podriva. Tehnika montaže strukturalnih i značenjskih dijelova pri tome je ključan postupak, na način kako se to često sreće $u$ avangardnim poetikama ${ }^{29}$. Pjesma kao cjelina funkcionira na principu supostavljanja ili suprotstavljanja semantičkih, prostornih ili vremenskih fragmenata, a njezin se učinak gradi na tenzijama koje se između njih uspostavljaju. Kao primjer za ilustraciju može poslužiti poema Vitez, hrast, miris vafla, pjesma posvećena 72. godišnjici pogubljenja partizanske herojke Mire Cikote koja je 1942. osuđena na smrt vješanjem. Osim tragične i hrabre smrti 30-godišnje žene (svjedoci navode da je sama navukla omču oko vrata) pjesma, međutim, podastire još nekoliko semantičkih blokova - prije svega, ljudi koji si bili povezani s Mirinom sudbinom (ustaški sudija Marić koji ju je osudio te doktor Mladen Stojanović, partizanski komandant, čiji je spomenik na suprotnoj strani trga gdje je obješena Cikota), ali i naizgled sasvim nepovezan intertekstualni motiv viteza Don Quijotea. Montažom semantičkih blokova gdje različiti ljudi, osuđeni od ideološki suprotstavljenih čimbenika (partizana i ustaša), završavaju istim tragičnim smrtima, na istom trgu, postiže se kontekst apsurda o kojem je bilo riječi ranije, a slika povijesti koja se pritom uspostavlja ukazuje na transformaciju vrijednosnih entiteta u njihove groteskne ili trivijalne pandane: „Na mjestu gdje su objesili Miru Cikotu, gdje je / poslije visio njezin sudija, gdje su hrast bogat oborili / - sada stoji divovski šestmetarski krst, u metalu i / bronci, / spomenik palim srpskim / borcima / Nakon novog rata". Umetanjem intertekstualne slike Don Qujitea koji isprobava svoj šljem pa ga, iako mu se učinio preslab, svejedno meće na glavu uvjerivši samoga sebe u ulogu viteza, narativne tenzije između povezanih semantičkih blokova još više rastu s maksimumom doživljajno-spoznajnog intenziteta na samom kraju pjesme koji

${ }^{29}$ Por. A. Flaker, Poetika osporavanja, Zagreb 1982; S. Sorel, Hrvatsko avangardno pjesništvo, Rijeka 2009. 
i završava motivom smiješnih mačeva kao aluzijom na grotesnu i apsurdnu stranu povijesti ovih prostora obilježene višestrukim, ponavljajućim ratovanjima.

\section{Novotvorenice i nonsensne semantostrukture}

Novotvorenice su najprepoznatljivije formalno obilježje Cvijetićeve poezije, a za ovu ćemo ih svrhu razmotriti zajedno s nešto složenijim leksičkim cjelinama obilježenim odmakom od logične konstelacije stvarnosti - nonsensnim sematostrukturama. I za jedne i za druge ključan je odmak od normiranog jezika prema neuobičajenom, začudnom ili nonsensnom. Bezbroj je primjera neologizama u svim zbirkama ovoga autora. Navest ćemo tek nekoliko koje su povezane sa semantičkim poljem smrti: „A zemlja već / Udahnuta / Čeka nekoljicu“ (Čičin rovovnik, zbirka Masovne razglednice iz Bosne); „Zemlja / nastećkana / minama“ (Snajperisti kod Godota, zbirka Masovne razglednice iz Bosne), „Odjenuti se za / Groboćaskanje“ (Dan pred marširanje, zbirka Konopci s otiskom vrata), „Meso me napušta / Prelopatano“ (Stećak o Tesli, zbirka Mali ekshumatorski eseji). Svi navedeni neologizmi (nekoljica, rovovnik, nastećkana, groboćaskanje, prelopatano) vezani su za problematiku smrti i to nasilnih smrti, obilježenih klanjem (odatle i izvrsna, antonimna joj imenica nekoljica), ratnim ukapanjima i postratnim iskapanjima (odatle pridjev prelopatan, kao oznaka stanja tijela koje trpi lopatanje i težinu zasipane zemlje) i masovnim ukopima koji zemlju čine nastećkanom grobnim spomenicima te joj priskrbljuju groboćaskanja (kako ispod, tako i iznad zemljine površine).

Za razliku od novotvorenica koje uglavnom čuvaju prepoznatljivu vezu sa svojim tvorbenim ishodištem, a time i semantičku transparentnost, Cvijetićeva poezija povremeno rabi i kompleksnije strukture (sintagme pa i čitave stihove ili strofe) kod kojih denotativna razina izmiče ili je obilježena potpunim otklonom od logike stvarnosti. Donosimo ovdje dva primjera, oba u vezi s tematikom smrti: „Kada su otvorili masovnu na / Jakarinoj kosi dvijeidvanaeste / sa 373 tijela / vidjeli su I. G. (1968) kako čuči / U materinoj košulji. / Kosa mu se slijepila / Od gline na tavanu. / I još veli: / Pa gdje ste vi dosad?" (Bicikl od kose, iz Konopci s otiskom vrata); „Djed Mrazovi / Čekaju bus kod / Pogrebnog zavoda“ (Novogodišnja, iz Konopci $s$ otiskom vrata). Prvi primjer ukazuje na nemoguću situaciju nalaženja živog čovjeka u masovnoj grobnici koja bi se, da je riječ o drugom iskaznom modusu možda mogla shvatiti i fantastično, no u ovom slučaju - kako zbog dokumentarnih detalja, tako i zbog ironičnog pitanja „Pa gdje ste vi dosad?“ - jasno je da je riječ o autorskoj strategiji ukazivanja na apsurd ratnog i postratnog konteksta Bosne i Hercegovine kao, uostalom, temeljnoj autorskoj intenciji cijeloga opusa. Drugi primjer jest nešto ludičniji, neočekivaniji, u maniri groteske koje se postiže posezanjem za infantilnim motivom Djeda Mraza ${ }^{30}$. Semantičkim sučeljevanjem ‘Djeda Mrazova' i ‘Po-

${ }^{30}$ Motivi likova iz bajki, priča za djecu, animiranih filmova i slično česti su intertekstualni motivi i u drugim Cvijetićevim pjesmama, npr. Snjeguljica, Crvenkapa, Petar Pan, Mačak u čizmama, Mali princ, Pokemoni i sl. 
grebnog zavoda' postiže se tzv. visoka tenzija pjesme o kojoj govori Allen Tate ${ }^{31}$ iz koje opet proizlazi apsurd kao temeljni doživljajno-spoznajni okvir.

\section{Zaključak: odraz smrti u jeziku principom klepsidre}

Pjesnički opus D. Cvijetića u znaku je smrti. Smrt je semantički obzor ove poezije koji joj osigurava široku lepezu motiva, najčešće iz ratne i postratne stvarnosti, ali i svjetonazorsku i ugođajnu esenciju koja ukazuje na smislenu nedohvatljivost života obilježenog nedokučivim i apsurdnim ranjavanjima. Zvjerske crte čovjeka, kao i groteskne crte života uopće, trajna su opsesija ove poezije koja u boli (ljudi, životinja, pa i stvari) pronalazi temeljni referencijski okvir. Ono što, međutim, ovu poeziju čini prepoznatljivom jest način na koji se smrt kao referencijsko uporište i jezični označitelj koji je prenosi međusobno odnose - povezuje ih ekscesnost kao temeljni impuls iz kojega izvire ova poezija i koji je suštinski determinira. Smrti u ovim tekstovima redovito su neočekivane, ekscesne smrti bilo da je riječ o ratu, zločinu ili nesretnom slučaju. S druge strane, Cvijetićev je jezik također ekscesan jezik - onaj koji se odmiče od uobičajenog ili očekivanog oblika i progovara svojom odmakom od neutralnog iskaza. Ekscesnost smrti kao čovjeku najnedokučivijeg referenta prati tako ekscesnost pjesničkoga jezika, ali na način koji nije način komplementarnosti, nego obrnutosti, odnosno - principom klepsidre. Šokante činjenice ranjavanja i smrti, osobito onih najslabijih kao što su djeca ili životinje, tragični prizori zločina, krvi i postratnih iskapanja iskazuju se jezikom koji je po emotivnom naboju suprotan slikama koje izražava - utišanim i mirnim jezikom koji dodiruje rub izgovorivosti. Čitav je niz stilskih figura i pjesničkih strategija koje koristi ova poezija u takvoj intenciji, a među najznačajnije spadaju figure izokrenutog svijeta, supostavljanja narativnih tenzija u dužim pjesničkim formama te leksičko-sintagmatske figure tvorbe novih riječi i oblikovanja nonsensnih semantostruktura. Osim njih, dakako, tu je i niz drugih koje zbog prostorne ograničenosti ovdje nismo analizirali, kao što su litotizirane semantostrukture, kadriranje detalja, metaforičke semantostrukture, jezične igre, grafička organizacija teksta, simulacija govornog iskaza (rus. skaz) i druge. Većina navedenih postupaka karakteristična je za (neo)avangardne poetike kakvom možemo odrediti i Cvijetićevu, kako zbog samih iskaznih strategija tako i zbog svjetonazorske angažiranosti koja je prati, a koja je redovito okrenuta propagira nju humaniteta i osudi svih oblika fašističkih praksi.

Oslanjajući se na filozofsko-lingvističke poglede ranoga Wittgensteina, pjesništvo ovog pjesnika u poetskom mediju prezentira upravo ono o čemu je u Traktatu pisao Wittgenstein - da je transcendentno, kojemu pripada i poezija, neizgovorivo racionalnim jezikom. Iskliznuća u topos izokrenutog svijeta kao i brojne druge figure koje potvrđuju jezik začudnosti imaju upravo tu svrhu - da

${ }^{31}$ Usp. A. Tate, Tension in Poetry, [u:] idem, The Man of Letters in the Modern World: Selected Essays. 1928-1955, London 1955. 
pokažu kako je pred nedokučivim fenomenima kao što je smrt jezik onesposobljen u svom normalnom, uobičajenom liku. Pred potresnim i apsurdnim licem nasilnih i neočekivanih smrti jezik kao da se 'zbuni' i okrene u nešto drugo od onoga što inače jest $-u$ obrnute perspektive, $u$ riječi koje inače ne koristimo, u neobične pa i potpuno alogične konstrukcije. Odmicanjem od standarne jezične paradigme Cvijetićev pjesnički jezik istu ujedno prevrednuje - razmiče granice iskazivosti implicitno poručujući da je smrt, osobito ona od ruke drugoga čovjeka, trajno 'zatamnjeno' mjesto, točka gdje razum gubi bitku.

\section{Bibliografija}

Bulgakov M., Majstor i Margarita, prev. V. Flaker, Koprivnica 2012.

Cooke M., Deconstructing war discourse: Women's Participation in the Algerian Revolution, Women and International Development, prir. A. Ferguson, East Lansing 1989.

Cvijetić D., Noćni Gorbačov, Beograd 1990.

Cvijetić D., Himenica, Beograd 1996.

Cvijetić D., Manifest mlade Bosne, Novi Sad 1999.

Cvijetić D., Passport for Sforland, Banja Luka 2004.

Cvijetić D., Masovne razglednice iz Bosne, Banja Luka 2012.

Cvijetić D., Konopci s otiskom vrata, Prijedor 2013.

Cvijetić D., Mali ekshumatorski eseji, Banja Luka-Beograd 2015.

Cvijetić D., Emotikoni u Viberu, Sarajevo 2016.

Cvijetić D., Paraolimpijske himne, Ljubljana 2017.

Cvijetić D., Ježene kožice, Zenica 2017.

Demiragić A., Prikaz rata u tekstovima bosanskohercegovačkih spisateljica: žensko ratno pismo 1992.-1995., doktorska disertacija, Filozofski fakultet u Sarajevu, 2015.

Finci P., Umjetnost uništenog: estetika, rat i Holokaust, Zagreb 2005.

Flaker A., Poetika osporavanja, Zagreb 1982.

Kearl M. C., Endings: A Sociology of Death and Dying, New York-Oxford 1989.

Kos-Lajtman A., Poetika iskopavanja, kartografija ranjivosti, [u:] D. Cvijetić, Paraolimpijske himne, Ljubljana 2017.

Kovač E., Amazonke, vile i satirice, Čakovec 2011.

Morin E., Čovjek i smrt, Zagreb 2005.

Pavletić V, Ključ za modernu poeziju, Zagreb 1986.

Periša A., Poteškoće i mogućnosti govora o etičkom kod ranog Wittgensteina, „Crkva u svijetu“ 2006 , br. 1.

Solar M., Retorika postmoderne, Zagreb 2005.

Sorel S., Hrvatsko avangardno pjesništvo, Rijeka 2009.

Šuvaković M., Postmoderna (73 pojma), Beograd 1995.

Tate A., Tension in Poetry, [u:] idem, The Man of Letters in the Modern World, Selected Essays. 1928-1955, London 1955.

Žižek S., Sublimni objekt ideologije, Zagreb 2002.

White H., Figural Realism: Studies in the Mimesis Effect, Baltimore 1999.

Wittgenstein L., Tractatus logico-philosophicus, prev. G. Petrović, Zagreb 2003. 


\section{Death as a double excess in poetry of Darko Cvijetić}

\section{Summary}

The paper deals with the treatment of the theme of death in the poetry of the contemporary Bosnian author Darko Cvijetić. The author's opus is full of motifs of death, it is a kind of "poetics of death" which generates not only a complex "poetic gallery of the dead", but also a "gallery of the wounded", through a dehumanized image of war and post-war Bosnia. A demonic face of the late 20th and early 21st century Balkans is the basic semantic framework for most of Darko Cvijetić texts, death and wounds are his central motif places. In this postmodern opus (with expressive neo-avantgarde poetic gestures), death takes on determinants of accident and incident of the world, but of language as well. These two categories present in Cvijetić's poetics are paired on the principle of a clepsydra - the experiential signs of these two categories, however, are opposite to each other: accidental/violent death as a fact of maximum cognitive and emotional intensity in the poetic realization manifests as linguistically inferior or self-evident place devoid of rhetoric and pathos. The process of a mute language gesture sometimes goes to the level which is beyond reason; as such, it is in counterpoint to the semantics of signifier. The result of this tension is resolved as an implosion in the reader, while the text to the end remains rhetorically restrained.

Keywords: Bosnia, Darko Cvijetić, excess of the world, excess of the language, death as a case (accident)

\section{Śmierć jako podwójny eksces w poezji Darko Cvijeticia}

\section{Streszczenie}

Praca porusza zagadnienia śmierci w poezji współczesnego bośniacko-hercegowińskiego autora Darko Cvijeticia. Śmierć jest kluczowym motywem całego zbioru Cvijeticia i można tu mówić o „poetyce śmierci”, która generuje nie tylko złożoną galerię martwych, lecz także galerię ranionych na podstawie zdehumanizowanego obrazu wojennej i powojennej Bośni. Demoniczna twarz Bałkanów na przełomie stuleci jest podstawową ramą semantyczną większości tekstów Cvijeticia, podczas gdy śmierć i rany są wiodącymi motywami miejscowymi. W tej postmodernistycznej twórczości (wyrażonej neoawangardowymi szkicami) śmierć staje się wyznacznikiem przypadkowości i ekscesu — zarówno świata, jak i języka. Dwie ostatnie kategorie w poezji Cvijeticia łączą się na zasadzie klepsydry - ich empiryczne oznaki są jednak przeciwne: przypadkowa/gwałtowna śmierć jako fakt maksymalnego poznawczo-emocjonalnego nasilenia w poetyckiej realizacji manifestuje się jako językowo gorsze lub oczywiste miejsce pozbawione retoryki i patosu. Proces wyciszania językowych gestów czasami sięga do krawędzi rozumu i jako taki staje w kontrapunkcie z semantyką oznaczonego. Efekt przytoczonych napięć rozwiązuje się jako implozja w czytelniku, podczas gdy tekst do końca pozostaje retorycznie ograniczony.

Kluczowe słowa: Bośnia, Darko Cvijetić, ekscesy świata, ekscesy języka, śmierć jako przy-/ wy-padek 